\title{
THE LEGAL ADVICE OF TOTOES IN THE SIUT ARCHIVE (P. BM 10591, VERSO, COL. I-III)*
}

\author{
By Gert Baetens and Mark Depauw
}

This article offers a new interpretation of the enigmatic first three columns of the verso of P. BM I059I from the Siut archive. The two texts recorded in these columns offer a unique insight into the processing methods of Ptolemaic petitions and the use of Greek and Demotic in the Ptolemaic administration. After the presentation of a new transliteration and translation, the legal and administrative context of these texts is scrutinized.

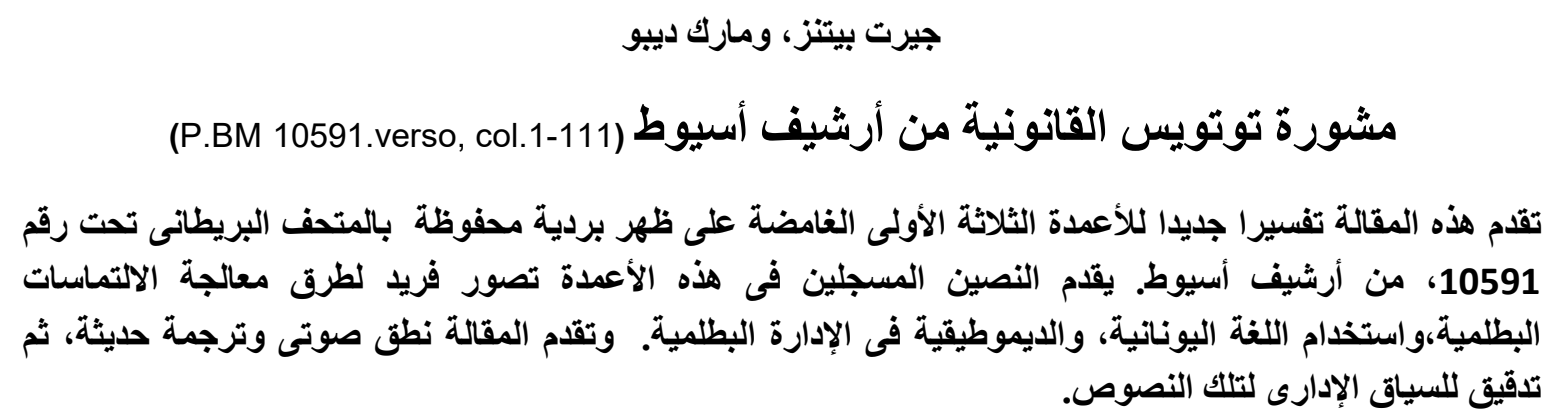

ThE Siut archive, with papyri dealing with an inheritance dispute in the second century $\mathrm{BC}$, is one of the principal sources for our knowledge of the indigenous judicial system of Ptolemaic Egypt. ${ }^{\mathrm{I}}$ The core document of the archive (P. BM 1059I) is an impressive $285 \mathrm{~cm}$ long with writing on both sides. The recto records the trial between Cratianch and Tefhape before the laokritai court of Siut in 170 BC. $^{2}$ On the verso several texts are written in another hand and a lot of space is left blank. Two of these

* We would like to express our most sincere gratitude to Sandra Lippert, who revealed herself as one of the anonymous reviewers of this paper and a better specialist in Demotic law than Totoes. Her elaborate comments greatly improved our understanding of the text and certainly warranted co-authorship, which she nevertheless declined. We also want to thank Willy Clarysse, for reading this text with us, and Brian Muhs, who forwarded us the text of his unpublished paper on priests and pastophoroi, presented at the $8^{\text {th }}$ Demotic Congress in Würzburg (2002). Lastly, we are very thankful to the staff of the British Museum for providing access to the original.

I Editio princeps in H. Thompson, A Family Archive from Siut from Papyri in the British Museum Including an Account of a Trial before the Laocritae in the Year BC I7O (Oxford, I934). Two additional texts were published later on: A. F. Shore and H. S. Smith, 'Two Unpublished Demotic Documents from the Asyut Archive', $\mathcal{F E A} 45$ (1 959), 52-60. Bahar Landsberger (Heidelberg) is currently preparing a new edition of the archive.

${ }_{2}$ Cf. recent works by Manning: J. G. Manning, Land and Power in Ptolemaic Egypt: The Structure of Land Tenure 332-30 BCE (Cambridge, 2003), 20I-5; J. G. Manning, The Last Pharaohs: Egypt under the Ptolemies, 305-30 BC (Princeton, 2010), 207-I6; J. G. Manning, 'Courts, Justice and Culture in Ptolemaic Law: Or the Rise of the Egyptian Jurists', in H. D. Baker, M. J. Jursa, and H. Täuber (eds), Administration, Law and Administrative Law: Proceedings of the 2nd International Conference of the NFN Imperium and Officium (Vienna, forthcoming). 
texts (col. I-III), however, are apparently unrelated to the rest of the papyrus and the other documents of the archive. The first one (col. I-II) is a petition of the priests of Syene to Noumenios, a high-standing official of the Ptolemaic regime. Beneath the petition are two subscriptions that ask for the legal advice of Totoes son of Petehyris, 'who writes for the judges, namely the priests of Onuris'. The reply of this legal expert is provided in the second text (col. III). After the editio princeps of these two texts by Thompson, several corrections have been made. ${ }^{3}$ Recently Quack has published a new edition, in which he incorporates these corrections and offers some additional new readings, with a summary of the content of the texts. ${ }^{4}$ Despite the great merit of Quack's work, several aspects of the texts have remained somewhat obscure. In this article, we would like to suggest some new readings on the basis of an inspection of the original (3 April 2014) and reinterpret the two texts in their legal context.

\section{The petition to Noumenios (P. BM 10591, verso, col. I-II)}

(I. I) w'mkmk (n) Nwmnys (2) n- $\underline{d}$ r.t nz w'b.w 3s.t irm n3 ntr.w nty htp irm $\{=f\}<=s>$ (3) n p3 rpy 3s.tnty (n) Swn hpr ḩ3.t-[sp] II (4) ibd-4 šmw tw=n n=kw'mkmk (5) iw =n ir-w3h r nзy=n

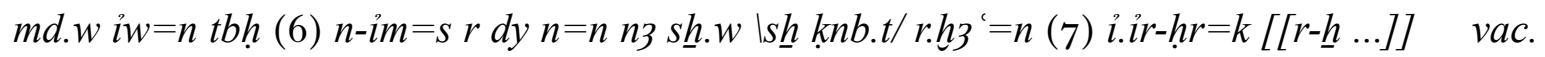

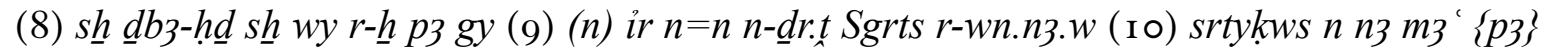

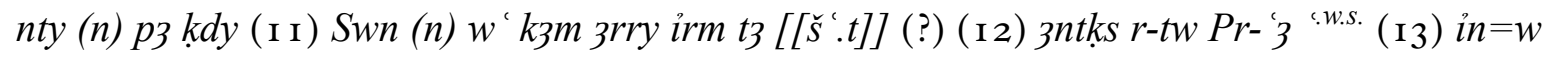

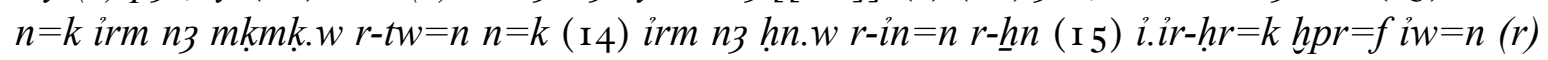

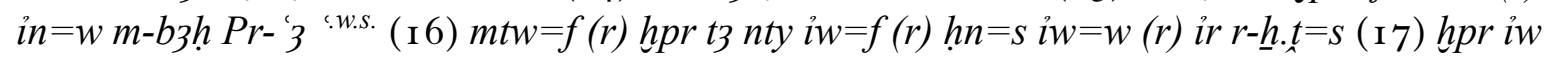

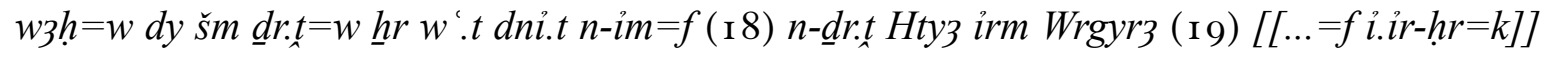

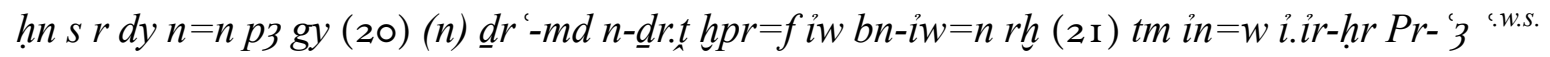
$n 3 g y$ (22) (n) $\underline{d} r^{\prime}-m d r n=w$ hpr=fiw bn-iw k.t (23) rygy st3.t $r-h r=n$ (n) $\underline{h}^{\prime}$ (24) $m t w=k h^{\prime}=k$

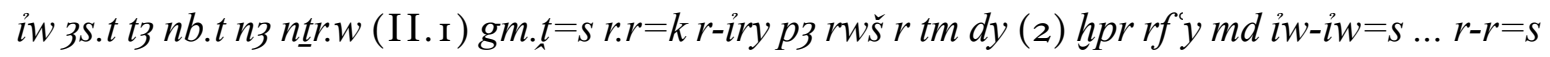
(3) dbj hpr iw n3 grr.w irm n3 wtn.w (4) nty iw hr hpr iri=w s iw hr in=w s (n) p3 hm (n) (5)

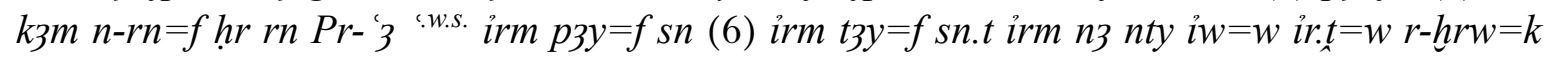
$t w=n(7) t b h n . i m=s \quad$ vac. $\quad(8) m t w=k i w-i w=s h s(r) h n=s r h b$ (9) Ssyns $p 3$ ' $n$ rsy.t ( о o)

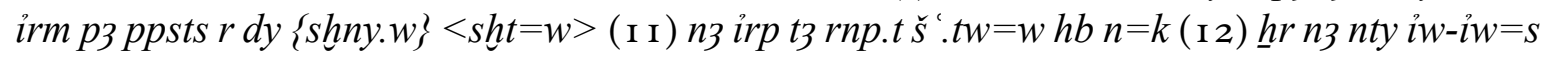
(r) $p h n h 3 . t=w \underline{h} r n 3 y$ (13) $r$-hrw Pr- 3 'w.s. hpr=fi.ir n3y hpr (14) iw p3 hp ir.t $n=n$ (n) rn=k

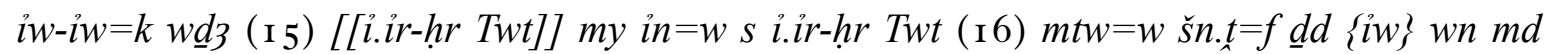

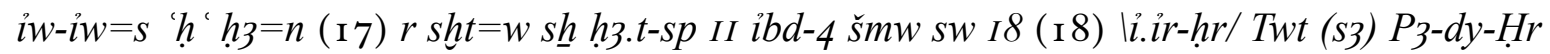

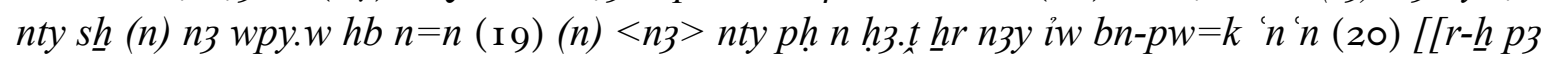
$h(p)]]$ sh ḩ $3 . t-s p$ II $i b d-4 \check{s} m w$ sw I9

(I.I) A memorandum to Noumenios from the priests of Isis and the gods that rest with him (sic) in the temple of Isis in Syene. It happened in year I I, Mesore, that we have given you a memorandum, (5) making explanations concerning our affairs and asking to give us the documents, \the official deeds/ that we left with you aceording to ... (vac.), a document of payment and a document of withdrawal, in accordance with the way

\footnotetext{
DemBL 95; M. Depauw, The Demotic Letter: A Study of Epistolographic Scribal Traditions against their Intra- and Intercultural Background (DemStud I4; Sommerhausen, 2006), 354-7; S. Lippert, Ein demotisches juristisches Lehrbuch: Untersuchungen zu Papyrus Berlin P 23757 rto (ÄA 66; Wiesbaden, 2004), 45.

4 J. F. Quack, 'Das Diktum des Tutu über die Eingabe an Numenios', in A. Jördens and J. F. Quack (eds), Ägypten zwischen innerem Zwist und äußerem Druck: die Zeit Ptolemaios' VI. bis VIII. Internationales Symposion Heidelberg I6.-19.9.2007 (Wiesbaden, 201 I), 268-75.
} 
of acting for us by Sokrates, who was (Io) strategos of the districts which are in the surroundings of Syene, concerning a vineyard, together with the teter of (?) enteuxis which Pharaoh 1.p.h. has caused to be brought to you, and the memoranda which we have given to you, and the orders which we have brought in (I 5) before you, so that it may happen that we bring them before Pharaoh ${ }^{\text {l.p.h. }}$ and that they will act according to what he will order, as hands have already been laid on a part of it by Hetia and Wergira. ... you order to give us (20) the official documents, because we have to bring them before Pharaoh 1.p.h., the official documents in question, lest another obstruction will come back to us in the end from you yourself. Isis, the mistress of the gods, (II. I) will hold it against you. Take care not to let negligence arise in business that ... her, because the burnt offerings and libations that commonly happen, they perform them while they are commonly brought from the aforesaid small (5) vineyard, for Pharaoh ${ }^{\text {l.p.h. }}$ and his brother and sister, together with the things which are done at your command. We ask (vac.) you, if it pleases, to order to write to Sisines, the archiphylakites and ( Iо) to the epistates to let the wines of this year be blocked until they write to you concerning what will be decided about these things at the order of Pharaoh ${ }^{\text {l.p.h. }}$, so that, if this happens, justice is done for us in your name, while you are doing fine.

( 1 5) To Totoes May it be brought before Totoes and may he be questioned: 'Is there anything that impedes us from blocking them?' Written in year I I, Mesore I 8.

$\backslash \mathrm{To} /$ Totoes son of Petehyris, who writes for the judges. Write to us what the decision is about these things, without being negligent, (20) in accordance with the law. Written in year I I, Mesore I 9 .

Col. I

I.I. For information and bibliography on Noumenios, see: W. Huß, Ägypten in hellenistischer Zeit 332-30 v. Chr. (Munich, 200I), 579; E. Van 't Dack, Ptolemaica selecta: études sur l'armée et l'administration lagides (Studia Hellenistica 29; Leuven, I 988), 325-7. The scribe accidentally wrote $i r m=f$ instead of $i r m=s .{ }^{5}$

I.3-4. The absence of the precise day in the reference to the date when the $m k m k$ was handed over to Noumenios is remarkable, especially since receipts, letters and memoranda are normally precisely dated in the Demotic tradition, unlike contracts. Since this $m k m k$ is dated in the same month, at most only two and a half weeks later, it is almost tempting to assume that there never was a previous memorandum and that this is some kind of epistolary past, referring to itself. There seem to be no parallels for this, however, and in col. IV line 3 a similar formula referring to an actual earlier memorandum appears. Therefore we have assumed that the matter is better explained by accepting that a previous memorandum existed and this is just a 'reminder' because the matter was really urgent. Similarly, line $\mathrm{I} 3$ requests the return of multiple petitions to Noumenios about the same case, preceding even this previous memorandum.

\footnotetext{
$5 \quad$ Thompson, A Family Archive, 50; Quack, in Jördens and Quack (eds), Ägypten zwischen innerem Zwist und äußerem Druck, 270.
} 
I.5. Literally $i r$-w3h means 'to answer'. ${ }^{6}$ The element $w 3 h$ has a distinctive form in this text, with a curved lower left side, similar to $\underline{h} \underline{d}$.

I.6. Depauw, followed by Quack, has read the supralinear addition as $r m \underline{t} n h t . t$, 'trustee'. But it would be strange if this addition would be inserted between $n 3 s \underline{h} . w$ and $r . h_{3}{ }^{\prime}=n$, especially because ample space is available between $n=n$ and $n_{3}$, where it would be more expected. Moreover the group is not included in the quote of this passage in col. III, line 6 (cf. the appendix below for a comparison of the two versions), which is also surprising if it adduces a new element such as 'trustee'. The new reading $s \underline{h} k n b . t$ certainly fits better as a (less crucial) addition to $n_{3} s \underline{h} . w$, as Lippert argues that $s \underline{h} k n b . t$ were deeds that served as evidence before court. ${ }^{8}$ Although not immediately obvious, this new reading seems palaeographically plausible as well. Because of the small size, the horizontal stroke of $s \underline{h}$ has become a small blot. The main sign of $k n b . t$ can be read as having two vertical strokes, the first crossing the horizontal stroke, as usual. A comparison with $s \underline{h} k n b . t$ in col. IV, line 7 confirms the reading.

I.7. Elsewhere in the text (col. I, line 20; col. II, line I 5, 20) words are clearly scratched out by means of vertical scribbles. The words at the end of this line, however, are smudged in a very different manner, comparable to col. I, line I I and col. III, line Io. It cannot be excluded that this happened by accident, but perhaps it would be too much of a coincidence that the words just before the smudged parts would have remained untouched by these accidents. Moreover, the blurred parts of line 7 and I I are not needed at all to have a meaningful text.

Quack has read the end of line 7 as $r-\underline{h} w^{\prime} . t$ dni.t, on the basis of the writing of $w^{\prime} . t$ dni.t in line $\mathrm{I} 7$ of the same column, ${ }^{9}$ but dni.t is written differently there. An inspection of the original clearly showed that the sign read by Quack as $w^{\prime} \cdot t$ consists of a vertical line only. Perhaps the word after $r-\underline{h}$ might be read ip.t ('according to $<$ the $>$ list'), but in that case the article would be missing.

Presumably the end of the line was left blank on account of the enumeration of documents that follows.

I.8-I I. Normally, (n) w' k3m zrry would be expected directly after $s \underline{h} \underline{d} \underline{d} b 3-\underline{h} \underline{d} s \underline{h} w y$. Moreover, it is not clear what is meant exactly by $r-\underline{h} p_{3} g y(n)$ ir $n=n n-\underline{d}$ r.t Sgrts. Locher argues that Sokrates, about whom not much more is known, exercised his duties from

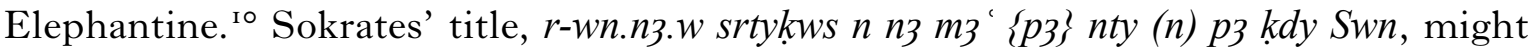

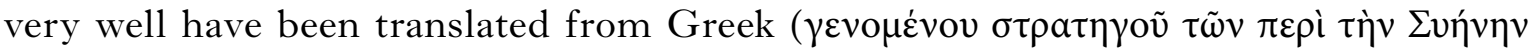
$\tau o ́ \pi \omega \nu$ ). Perhaps the Greek primary version of this text (cf. interpretation) might account for the strange syntax.

\footnotetext{
Quack, in Jördens and Quack (eds), Ägypten zwischen innerem Zwist und äußerem Druck, 270.

Depauw, The Demotic Letter, 355; Quack, in Jördens and Quack (eds), Ägypten zwischen innerem Zwist 7 Depauw, The D

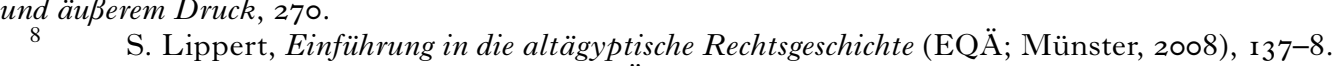

Quack, in Jördens and Quack (eds), Ägypten zwischen innerem Zwist und äußerem Druck, 270.

Io J. Locher, Topographie und Geschichte der Region am ersten Nilkatarakt in griechisch-römischer Zeit (AfP Beiheft 5; Stuttgart, I999), 28. For further information and bibliography on Sokrates, see: L. Mooren, 'The Strategos Athenaios, His Subordinate Nestor, and the Administrative Organization of the Southern Thebaid', CdE 55 (1980), 262-70.
} 
I.9. The plural strokes of $n=n$ are missing, but the reading is certain thanks to the quote from this document in col. III, line 7 (cf. appendix).

I. Io. There is a superfluous $p 3$ which has been omitted in the quote from this document provided in col. III, line 8 (cf. appendix).

I. I I-I 2. Depauw has convincingly argued that $3 n t k s$ must be the Demotic transliteration

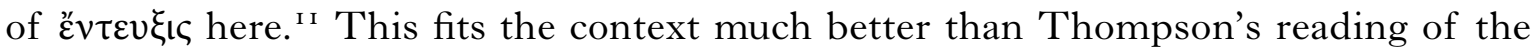
name Antiochos. ${ }^{\mathrm{I} 2}$ Just like in line 7, the last part of line i I has been smudged on purpose or by accident. Thompson cautiously suggests to read it as $r y . t$, but this seems palaeographically impossible and its meaning would be obscure. ${ }^{13}$ We suggest to read it as $\check{s} . t$ : 'a letter of enteuxis'.

I. I 5. A small vertical stroke appears between $h p r$ and $=f$, but this appears to be an orthographical peculiarity, encountered in line 20 of the same column as well.

I.I6. t3 $n t y i w=f(r) h n=s$ is a typical example of frontal extraposition. ${ }^{14}$

I.r8. In col. III, line ro, the second individual is named Wrgyz instead of Wrgyr3. Probably these names are Nubian or Blemmyan. ${ }^{15}$ The people are otherwise unknown.

I. I 9. The words at the beginning of this line were intentionally scratched out. Thompson and Quack read the passage as $[[h p r=f i w w 3 h=k]] .{ }^{16}$ A construction in the perfect tense seems strange here, but after all the words may have been scratched out because they were incorrect. On the other hand, an examination of the original papyrus favours the reading $i . i r-h r=k$ for the last scribbled group. Depauw has previously suggested $[[h p r=f$ i.ir- $h r=k]],{ }^{17}$ but after $h p r=f$ one would expect $i w$. Another problem with both readings is that there appears to be a sign between $h p r$ and $f$. Perhaps the group read as $h p r$ needs to be interpreted differently. The imperative $h n$ is not very polite; the erased part might contain a more elaborate expression, which the scribe copied incorrectly.

I. 19-20. Rather than references to the documents themselves, as proposed by Depauw, Quack argues that $g y(n) \underline{d} r^{\prime}-m d$ refers to the act of registration, with the abstractbuilding gy: 'uns die Registrierung zu gewähren' (line I9-20) and 'die besagten Registrierungen' (line 2I-22). ${ }^{18}$ Several examples from the Archive of Hor, however, show clearly that this expression did not necessarily refer to a process, as maintained

\footnotetext{
II Depauw, The Demotic Letter, 355. A similar transliteration of this word is found in P. Erbstreit I 7, 9; P. Erbstreit i 8, i 6 .

I2 Thompson, A Family Archive, 49-50.

I3 Thompson, A Family Archive, 50.

I4 R. S. Simpson, Demotic Grammar in the Ptolemaic Sacerdotal Decrees (Oxford, I 996), I78-8I.

I5 Quack, in Jördens and Quack (eds), Ägypten zwischen innerem Zwist und äußerem Druck, 27I

16 Quack, in Jördens and Quack (eds), Ägypten zwischen innerem Zwist und äußerem Druck, 269; Thompson, A Family Archive, 50.

${ }_{17}$ Depauw, The Demotic Letter, 355.

18 Depauw, The Demotic Letter, 355; Quack, in Jördens and Quack (eds), Ägypten zwischen innerem Zwist und äußerem Druck, 27I.
} 
by Quack, but could at least occasionally designate physical documents as well. ${ }^{19}$ In this case a similar interpretation of $g y(n) \underline{d} r^{\prime}-m d$ as a collective term, referring to the physical documents which the petitioners wished to retrieve, seems best. Because of its collective use, $g y(n) d r^{\prime}-m d$ is referred to in singular in line I 9 , but in plural in line $2 \mathrm{I}$ and 22. This fits the contents much better (cf. interpretation).

I.20-2 I. Depauw considered $t m$ as a mistake. ${ }^{20}$ But double negative constructions with $b n$-iw, $r h$ and $t m$, expressing a necessity, 'we have to', have been attested elsewhere, so no error has to be taken into account. ${ }^{21}$

I.23-24. There are some arguments in favour of Depauw's reading $n t y i w=k h n n=n$ $\underline{h}^{\prime} m t w=k h^{\prime}=k$ : the sharp-edged $n t y$ (as observed elsewhere in the text) could form a ligature with the suffix $=k$, written with a thicker line. ${ }^{22}$ But the $h$ of the assumed $h n$ seems to consist of two strokes, and the shape of its $n$ is also unusual. Therefore, we opt for the new reading by Quack, although the use of $s \underline{t} 3 . t$ is perhaps rather unexpected in this context. ${ }^{23}$

Thompson's reading, in which $m t w=k$ (in his interpretation an independent pronoun) is connected to what follows and even further emphasised by its frontal position and $h^{`}=k$, 'yourself', seems unusual. We have interpreted $m t w=k$ as a prepositional clause dependent from the previous sentence, like Depauw and Quack have done before: the priests of Syene say openly that Noumenios could be responsible for ruining their case. This seems rather direct, but the same is the case for the following statements of the priests.

\section{Col. II}

II. I. The expression gm.t $X r Y$ is known from other legal documents. In most cases gm.t is followed by a debt. ${ }^{24}$ But in the priestly statutes from Soknopaiou Nesos, the expression appears with a suffix $=s$ after gm.t, referring to forbidden actions: $i w=w$ $g m . t=s r-r=f m t w=f d i \ldots n k n s n n z w^{\prime} b . w$, 'when they find it against him, he will pay ... as penalty to the priests'. ${ }^{25}$ However rude, the priests of Syene seem to insinuate that Noumenios risks divine sanction if he does not tend to their business.

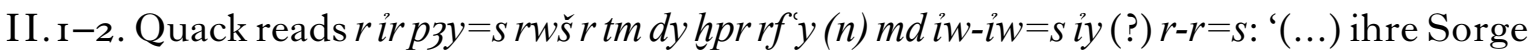
für dich auszuüben, um zu verhindern, daß Wanken entsteht in einer Angelegenheit, die gegen sie kommt' ${ }^{26}$ But it seems problematic that Isis would take care to prevent

I9 O. Hor I9, Ro I 7; O. Hor 23, Ro 9-10 and Vo I 2; O. Hor 30, 3.

20 Depauw, The Demotic Letter, 355 .

21 Quack, in Jördens and Quack (eds), Ägypten zwischen innerem Zwist und äußerem Druck, 271; Thompson, A Family Archive, 50. Cf. W. Spiegelberg, Demotische Grammatik (Heidelberg, I 925), § 48I .

$22 \quad$ Depauw, The Demotic Letter, 355.

23 Quack, in Jördens and Quack (eds), Ägypten zwischen innerem Zwist und äußerem Druck, 271.

24 P. Mattha 6, I2; O. Tempeleide 78, 4; O. Tempeleide I36, 4; O. Tempeleide I43, 4.

25 S. Lippert, 'Die Abmachungen der Priester-Einblicke in das Leben und Arbeiten in Soknopaiou Nesos', in P. Davoli and M. Capasso (eds), New Archaeological and Papyrological Researches on the Fayyum: Proceedings of the International Meeting of Egyptology and Papyrology. Lecce, Fune 8th-Ioth 2005 (Papyrologica Lupiensia I4; Lecce, 2005), I 50.

${ }_{26}$ Lippert, in Davoli and Capasso (eds), New Archaeological and Papyrological Researches, I 50. 
$r f^{\prime} y$ in things that go against her. One would expect the circumstantial sentence to specify $m d$ as business that is important for Isis, or that brings profit to her (i.e. the wine produce used to bring royal offerings). Still, we cannot offer a better reading than $i y$. For in, the upper part of the sign is slightly too flat and the direct object would be missing.

This problem can also be solved, however, by reading $r$-iry (imperative) instead of $r$ ir $p_{3} y=s$ (like previously argued by Depauw and Quack). The writing for iry is a little awkward in this case: normally the last stroke should be slightly curved to the left. But the whole makes much more sense: Noumenios is warned to protect the interests of Isis.

II.5-6. This text refers to the 'triumvirate' of Ptolemy VI, Kleopatra II and Ptolemy VIII. Thompson reads sister $(t 3 y=f s n . t)$ first and brother $(p 3 y=f s n)$ next, Quack reads the opposite. ${ }^{27}$ The only difference between both word groups is the stroke behind the first $s n$ sign. Thompson interprets this sign as a god's determinative, granted to Kleopatra II but not to Ptolemy VIII, because he had only recently joined his brother and sister in ruling. But there would be no other evidence besides this that Ptolemy VIII was not deified along with his brother and sister when he became co-regent. In fact, we know for sure that he was deified together with them at some point as the mother-loving gods. ${ }^{28}$ The sequence male-female seems more logical and is attested elsewhere for this triumvirate. ${ }^{29}$

II.6-8. These lines are an almost literal translation of a typical closing formula in Greek

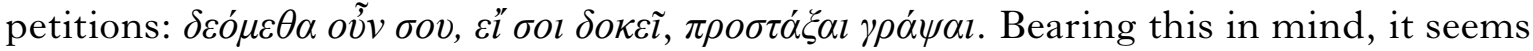
preferable to translate $h b$ as 'write' rather than Quack's 'ausschicken'. ${ }^{\circ}$

II.7. The rest of the line is left blank due to bad papyrus quality. ${ }^{3 \mathrm{I}}$

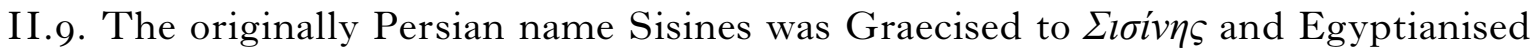
to Ssyns. ${ }^{32}$

II.9-Io. It is known from other sources that Ptolemaic police officers could combine the office of archiphylakites and epistates. ${ }^{33}$ But in all likelihood the archiphylakites (Sisines) and the epistates who are mentioned here are two different individuals. ${ }^{34}$ Otherwise the construction with irm and repetition of the article $p_{3}$ would be very unusual.

\footnotetext{
27 Quack, in Jördens and Quack (eds), Ägypten zwischen innerem Zwist und äußerem Druck, 269; Thompson, A Family Archive, 50-I.

28 ntr.w mr.w mw.t, not in dual but plural, see: M. Minas, 'Die Dekorationstätigkeit von Ptolemaios VI: Philometor und Ptolemaios VIII. Euergetes II. an ägyptischen Tempeln. Teil I', OLP 27 ( I 996), 76.

$29 \quad$ P. Genova 3 92, P. Ryl. Gr. 4 538, P. Tebt. 3 8 I I

30 Quack, in Jördens and Quack (eds), Ägypten zwischen innerem Zwist und äußerem Druck, 269. For hb, see: Depauw, The Demotic Letter, 255-7.

3I Cf. Thompson, A Family Archive, 5I; Quack, in Jördens and Quack (eds), Ägypten zwischen innerem Zwist und äußerem Druck, 27I.

${ }^{32}$ P. Huyse, Iranisches Personennamenbuch, 5: Iranische Namen in Nebenüberlieferungen indogermanischer Sprachen. Fasz. 6a: Iranische Namen in den griechischen Dokumenten Ägyptens (Vienna, I990), no. I I3. See the relevant Trismegistos record <www.trismegistos.org/name/5772>, accessed 21.04.201 5 .

33 J. Bauschatz and J. D. Sosin, 'Stealing Livestock at Oxyrhyncha', ZPE i46 (2004), i 67.
} 
II. Io. The emendation of shny.w to $s h t=w$ is certain on basis of the quote from this text in col. III, line 12 (cf. the appendix). ${ }^{35}$

II.I3-I4. The passage is a translation of the typical Greek closing formula tovitov $\delta \dot{\varepsilon}$

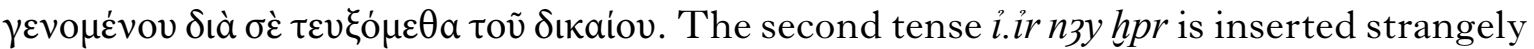
between $h p r=f$ and the depending circumstantial clause. But it must have been difficult

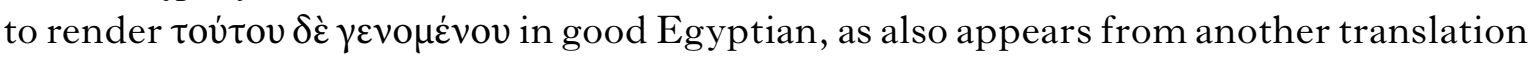
of the expression, in P. Eleph. Dem. I line I3: $h p r=f r i w=f h p r$. The identification with the Greek formula seems certain.

II. I 5. The scribe started copying line i 8 instead of line 15 here. For the interpretation of lines $\mathbf{I}^{-20}$ as two separate subscriptions, see the general commentary below.

II. I6. Quack notes that $i w$ after $\underline{d} d$ introducing a question is very unusual and suggests to emend this to $i n$, a more standard interrogative particle. But as $i w$ does not appear in

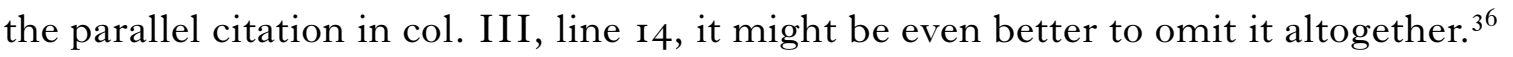

II. I 8. The title nty sh (n) nz wpy.w is used to designate the scribe of the judges. Totoes' title is more elaborate in lines $\mathrm{I}-2$ of col. III, where the judges in question are identified as 'the judges, namely the priests of Onuris, who judge in Ptolemais' ( $n_{3}$ wpy.w $n$ n3 w'b.w 'In-hr nty ir wpy (n) P3-sy). Undoubtedly this refers to the laokritai court scribe of Ptolemais. The Ptolemaic chrematistai courts, much better documented than the

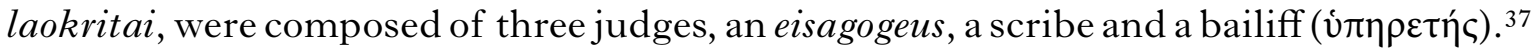
The laokritai courts seem to have been organized in exactly the same way. ${ }^{38}$

II.20. The scribe did not finish the word $h(p)$ and probably decided to strike out the entire reference to the law altogether. ${ }^{39}$

\section{The reply of Totoes (P. BM 10591, verso, col. III)}

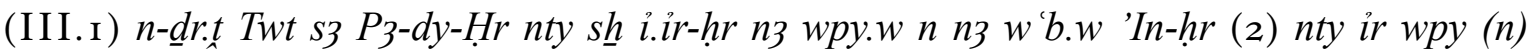

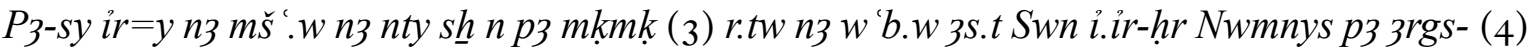

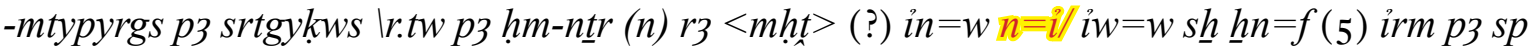

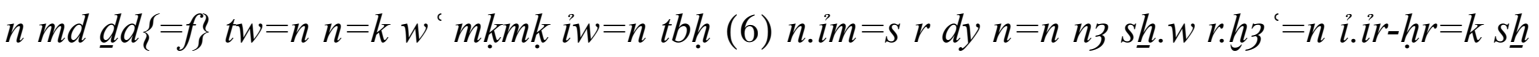
$\underline{d} b 3-\underline{h} \underline{d} s \underline{h} w y(7) r-\underline{h}$ p3 gy (n) ir $n=n$ n- $\underline{d}$.t. Sgrts $r$ wn-n3.w srtykws (8) nз m3 ' nty (n) p3 $k d y$

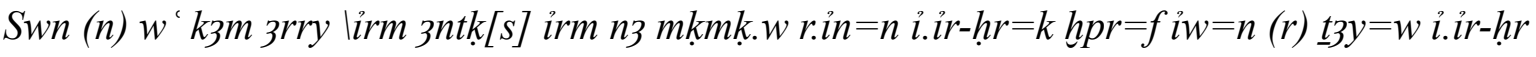

34 Cf. M. Depauw, 'Controlling the Perfume Monopoly: A Demotic Letter in Duke referring to a Proxy in Duke', ZPE I7I (2009), 203-4, where ppsts as rendering of epistates is also discussed. For the Demotic terminology used to designate the Ptolemaic police, see: W. Clarysse and D. J. Thompson, Counting the People in Hellenistic Egypt, II: Historical Studies (Cambridge, 2006), I66-8.

35 Depauw, The Demotic Letter, 355-6.

${ }^{6} 6$ Cf. Spiegelberg, Demotische Grammatik, $\$ 485,492$ for interrogative sentences without particle.

37 H. J. Wolff, Das Fustizwesen der Ptolemäer (2 revised edn; Munich, I 971), 68.

$3^{8} \quad$ In P. BM г 059 I, Ro, 'three judges' (col. I, lines 4-5; col. X, line I7-I9) are mentioned, assisted by an eisagogeus (col. I, lines 5-6), a scribe (col. VI, line 9; col. X, line I6) and a rd (col. X, line I4). P. Mallawi 602/ı。 equally mentions 'three judges' (lines 2, 23), a scribe (line 2I), a rd (lines 3, 22) and an eisagogeus who does not seem to be present (lines 4,22 ).

39 Cf. suggestion by Vleeming in Quack, in Jördens and Quack (eds), Ägypten zwischen innerem Zwist und äußerem Druck, 272.

comments ask to $\operatorname{correct} n=i$ to $n=y$ in line 4 , but the closest instance is this one, in line 3.

Change? 


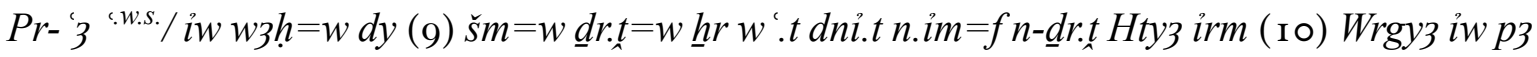

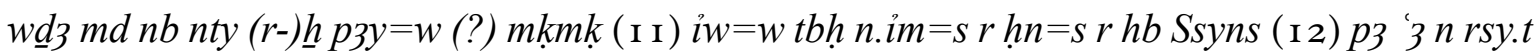

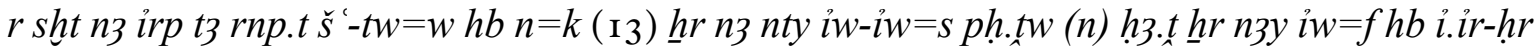

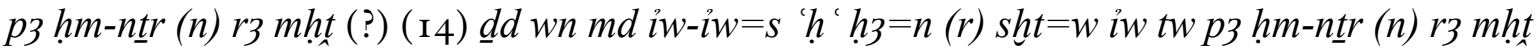

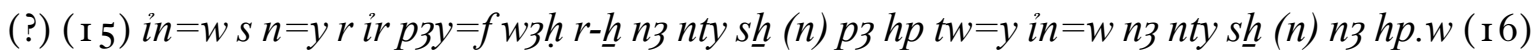

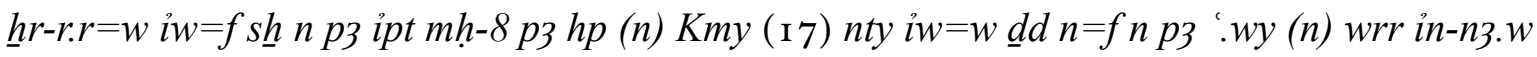

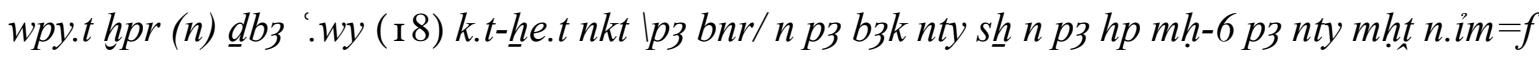

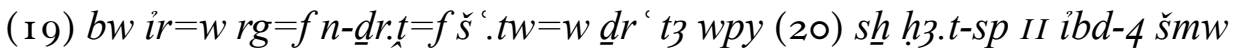

(III. I) From Totoes son of Petehyris, who writes for the judges, namely the priests of Onuris, who judge in Ptolemais. I have taken the steps which were written in the memorandum, which the priests of Isis of Syene gave to Noumenios, the archisomatophylax and strategos, \which the prophet of the <northern> gate (?) caused to be brought to me/, in which is written (5) among other things: 'we have given a you a memorandum, asking to give us the documents that we left with you, a document of payment and a document of withdrawal, in accordance with the way of acting for us by Sokrates who was strategos of the districts which are in the surroundings of Syene, (concerning) a vineyard, \together with the enteuxis and the memoranda which we brought to you, so it may happen that we take them before Pharaoh l.p.h./, as hands have been laid on a part of it by Hetia and ( 10 ) Wergia', while the rest (?) is everything which is according to their memorandum (?), while they ask 'to order to write to Sisines, the archiphylakites, to block the wines of this year until they write to you concerning what will be decided about these things', while it is written to the prophet of the northern gate (?), 'Is there something that impedes us from blocking them?', while the prophet of the northern gate (?) caused that (I 5 ) they brought it to me to formulate an answer to it according to what is written in the law. I let them bring what is written in the law concerning it, while it is written in the eighth table (?) of the law of Egypt which is called 'prison': if a trial is taking place about a house or other things \except/ for a slave, which is written in the sixth law, the one who is holding it, it is not seized from his hand until the judgement is written down. (20) Written in year I I, Mesore.

Col. III

III.I. The god Onuris was revered in Thinis, about $25 \mathrm{~km}$ south of Ptolemais. Thompson suggests that the priests of Onuris in Thinis were called upon to act as judges at Ptolemais, a Greek foundation without indigenous cults. ${ }^{40}$ Manning repeats this hypothesis. ${ }^{41}$ But perhaps there was a temple for Onuris in Ptolemais as well: in Gebel Toukh, the rock quarry that yielded material for construction in Ptolemais, there are several dedications to Onuris and Onuris-Shu, as well as inscriptions mentioning an individual named Nesonuris. ${ }^{42}$ Moreover, a fragment of a Demotic papyrus from the Ptolemaic period in the Cairo collection (P. Cairo II 30764) seems to refer to priests of Ptolemais who acted as judges.

III.2. $m \check{s} . w$ can indeed be used metaphorically as 'measures'. ${ }^{43}$

40 Thompson, A Family Archive, 52.

$4^{\mathrm{I}} \quad$ Manning, in Baker, Jursa, and Täuber (eds), Administration, Law and Administrative Law.

42 J. De Morgan, U. Bouriant, and G. Legrain, 'Note sur les carrières antiques de Ptolémaïs (Menchiyèh)', in Mémoires publiés par les membres de la Mission Archéologique française au Caire 8/3 (1 894), 375-6.

43 Cf. Thompson, A Family Archive, 52; P. Cairo 306 I 9, Ro 2.7. 
III.3. Something else was written on this line first, right up to the middle of the line where Nwmnys starts, but the scribe corrected himself. Most conspicuous is the sign just above 3s.t. The original sentence might have been something like $i n=w s p_{3} m_{3}$ nty iw Nwmnys $n$-im $=f$, but especially the second part of the lost signs is barely legible.

III.4. This line is in many respects problematic. The dot before $p 3$ hm-ntr, which also appears before $p_{3}$ srtgykws in the same line, $p_{3} s p$ in line $5, p_{3} g y$ in line $7, p_{3} \underline{h m-n t r}$ in line I 4 and $p_{3}$ '.wy in line I 7 , does not have to be read as $n$ but is clearly an orthographical peculiarity of the scribe. Thompson discerns the same phenomenon of a dot preceding p3 elsewhere on the verso (col. V, lines I I, I 7; col. VI, lines I 7, I 8, I 9) ${ }^{44} \mathrm{Col}$. IV of the verso is full of examples as well, especially-but not only-before titles (e.g. in lines 2, 4 and 5). No system can be discerned in the use of this dot.

The Demotic transliteration of strategos (srtgykws in this line) is unusual as well. The more common spelling srtykws is found in col. I, line ro and col. III, line 7.

Quack's reading of the end of the line as the name $n z-n h t=w-s$ seems hard to maintain: the vertical stroke after the house determinative looks like a mistake rather than $n_{3}$, and, except for the $n h t$-sign, $n h t=w-s$ seems no more than a Verlegenheitslesung. It seems even more improbable that the same name should be read in abbreviation at the end of line I3 $\left(n n^{<-n h t=w-S>) .}{ }^{45}\right.$ Moreover, the only name that appears in the Demotische Namenbuch (I 647) is $n h t=w-s$, without $n_{3}$. If one looks at the similar passage in lines I4-I 5, it makes much more sense to read the last four signs of line 4 as $i n=w n=y$. The scribe wrote the main in-sign and the dot beneath it with a single stroke, just like at the beginning of line 9 of col. IV. There is no resumptive pronoun $s$ after $i n=w$ because it would perform the function of direct object of a verbal form dependent from a past relative causative clause. ${ }^{46}$

Even then the reading of the group following $h m-n \underline{t} r$ remains problematic. The sign just behind $h m-n \underline{t} r$ is the same as in lines $\mathrm{I} 3$ and $\mathrm{I} 4$, but strangely enough the next signs appear to be different on all three lines. Quack reads $h m-n \underline{t} \mathbf{r}$ iri- ' $3 n_{3}-n h t=w-s$ in line 4 ,

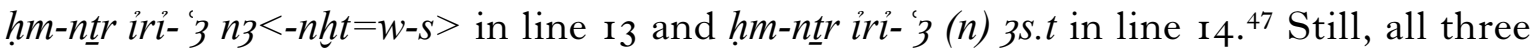
titles should refer to the same individual, namely the intermediary between Noumenios and Totoes, responsible for the transfer of the request for legal advice. Moreover, the combination of the function of prophet ( $h m-n \underline{t}$ r) and pastophoros (iri-' 3 ) would be highly unusual..$^{8}$ In a later article, together with Friedhelm Hoffmann, Quack admits that the

44 Thompson, A Family Archive, ıо7: 'euphonic, or simply a trick of writing'.

45 Cf. Quack, in Jördens and Quack (eds), Ägypten zwischen innerem Zwist und äußerem Druck, 273.

$46 \quad$ Cf. Spiegelberg, Demotische Grammatik, \$ 557.

47 Quack, in Jördens and Quack (eds), Ägypten zwischen innerem Zwist und äußerem Druck, $272-3$.

${ }_{48}$ Quack, in Jördens and Quack (eds), Ägypten zwischen innerem Zwist und äußerem Druck, 273 refers to a formula appearing in several contracts of individuals connected to Amenothes, son of Zoilos (cf. P. W. Pestman, J. Quaegebeur, and R. L. Vos, Recueil de textes démotiques et bilingues, II (Leiden, I 977) 76, 82, 88, 93-4): hmm-ntr w'b wn-pr izw.t nb shn nb (...). This is no true parallel, however. The Gnomon of the Idios Logos (\$ 71, 82, 94) states clearly that it was not allowed to combine these functions. Of course, these regulations date from the Roman period, but in the Ptolemaic period a clear distinction between priests and pastophoroi seems to have existed as well, as apparent in several formulae (cf. H.B. Schönborn, Die Pastophoren im Kult der ägyptischen Götter (Beiträge zur Klassischen Philologie 8o; Meissenheim am Glan, i976), 4-6). In an unpublished paper for the 8th Demotic Congress (Würzburg, 2002) Brian Muhs discussed the expression hmm-ntr w'b wn-pr ỉzw.t nb sḥn nb (...). He argued that where $s h n$ refers to private appointments (including the function of pastophoros), $i 3 w . t$ refers to offices, including the function of prophet. The above formula should not be interpreted as an individual title of the contractors, but indicates that the contractors held these sacerdotal rights collectively-which explains the 
reading $i r i-3$ is rather implausible. With reservations, they propose to read $w \underline{d} 3$, which would lead to the title 'the prophet of the granary' or 'the prophet of the Udjat-eye'. ${ }^{49}$ But neither of these titles is attested and the problem of the following signs would remain unsolved.

On the original papyrus one can clearly see that a vertical fiber of approx. $2 \mathrm{~mm}$ in width is missing, stretching from line 5 down to the bottom of the papyrus. At the right side of this fiber, another approx. I mm must have gone lost before the text was written, because the scribe has clearly written in it. The $2 \mathrm{~mm}$ lacuna has to be kept in mind when reading the group following $h m-n \underline{t} r$ in line $\mathrm{I} 3$ and I 4 . For the most elaborate group, in line I4, a short writing of mh.t might just be possible to read at the end, with the second sign partly in the lacuna. The sign that Quack interpreted as iri- 3 or $w \underline{d} 3$ might be read as $r_{3}$, resulting in $p 3 \underline{h m-n \underline{t} r}(n) r_{3} m \underline{h t}$ or 'prophet of the northern gate'..$^{\circ}$ The group behind $h m$-ntr in line 13 might be read $r 3 m h t$ as well, with only the end of the second sign of $m h t$ outside the lacuna. In line 4 , the scribe may have made a mistake: the house determinative is extended with a vertical stroke here. In his confusion the scribe may have forgotten to write $m h t$.

Several authors have argued that indigenous judicial practices in Egypt, including the laokritai-courts, often took place at the temple gate. ${ }^{5}{ }^{\text {I }}$ In this context Quaegebeur

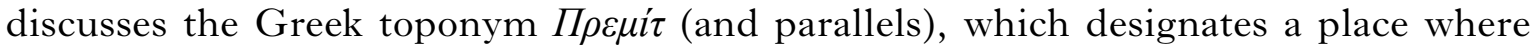
the strategos executes his judicial duties in P. Amherst II 35 (TM 862I), as well as the Demotic anthroponyms $\mathrm{Pa}-\mathrm{r} 3-\mathrm{mht}$ and $\mathrm{Ta}-\mathrm{p} 3-\mathrm{rz}-\mathrm{mht}$ that appear in several texts and mean 'him/her of the northern gate'. ${ }^{52}$ According to Quaegebeur these attestations refer to the practice of judicial duties at the northern temple gate, by the strategos and possibly

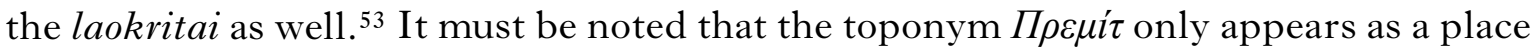
in Crocodilopolis in the Fayum. The anthroponyms, however, are attested in several parts of Egypt, so legal practices may have taken place at the northern gate of temples in other parts of Egypt as well, including Ptolemais. Since the $h m-n \underline{t} r$ appearing here was the intermediary between the strategos Noumenios and the legal expert Totoes,

fact that the formula is applied to several contractors at once. This explanation seems more plausible than the hypothesis in F. Hoffmann and J. F. Quack, 'Pastophoros', in A. M. Dodson, J. J. Johnston, and W. Monkhouse (eds), A Good Scribe and an Exceedingly Wise Man: Studies in Honour of W. F. Tait (London, 2014), 144-5, that in smaller temples these functions could be exercised by a single individual.

49 Hoffmann and Quack, in Dodson et al. (eds), A Good Scribe, I4I.

50 Quack has argued that $r 3$ and $w \underline{d} 3$ can be distinguished orthographically: J. F. Quack, 'Zu einigen demotischen Gruppen umstrittener Lesung oder problematischer Ableitung', in S. P. Vleeming (ed.), Aspects of Demotic Orthography: Acts of an International Colloquium held in Trier, 8 November 20IO (Leuven, 2013), I07-8. We agree with Quack about the essential distinction between the two words. In some texts $r 3$ and $w \underline{d} 3$ are indeed clearly written in different ways. But his argument that the horizontal base-line always crosses the vertical stroke in $w \underline{d} 3$, while it is set apart from or slightly touches the vertical in $r 3$ does not work for our text. If this hypothesis would be true the sign would have to be read $r_{3}$ in line 4 and $1_{4}$, but $w \underline{d}_{3}$ in line $\mathrm{I}_{3}$, while all three groups must clearly be the same. While the essential distinction that Quack makes, seems to be correct, both $r 3$ and $w \underline{d} 3$ could be simplified and written in the same way. Therefore we see no problem in reading $r_{3}$ in line $4, \mathrm{I}_{4}$ and $\mathrm{I}_{5}$ and $w \underline{d} 3$ in line ro (cf. below).

${ }_{51} \quad$ Cf. J. Quaegebeur, 'La justice à la porte des temples et le toponyme Premit', in C. Cannuyer and J. M. Kruchten (eds), Individu, société et spiritualité dans l'Egypte pharaonique et copte: Mélange égyptologiques offerts au Professeur A. Théodoridès (Athens, I993), 202-5 (including references to earlier articles on the subject); more recently J. G. Manning, 'The Representation of Justice in Ancient Egypt', Yale Fournal of Law and Humanities 24/I (20I I), I I 7-I 8 .

${ }_{52}$ See the relevant Trismegistos records <www.trismegistos.org/name/IO4I $5>$ and <www.trismegistos. org/name/ I 195>, accessed 21.04.2015.

53 Quaegebeur, in Cannuyer and Kruchten (eds), Individu, société et spiritualité. 
who himself is affiliated to the college of the laokritai, it seems sensible to connect the $h m-n t r$ to the 'northern gate', designating the place where Noumenios executed his duties in collaboration with the laokritai. Still, this title has not been attested elsewhere and the traces for $m h t$ are not perfect. Therefore the reading must remain tentative.

III.5. Quack transliterates $\underline{d} d r . t w=n$, but $r$ does not seem to make sense here, ${ }^{54}$ and the sign seems more like a small $f$. Perhaps the scribe accidentally wrote $\underline{d} d=f$, but this does not make much sense either. In any case the scribe seems to have been confused here: initially he also forgot the suffix $=n$ in $t w=n n=k w^{\prime} m k m k$, leading him to correct $n=k$ to $n$ and $w^{\prime}$ to $n=k$.

III.8. On the basis of the parallel section in col. I, line I2, 3ntk $[s]$ can be amended here instead of w3h. ${ }^{55}$ The scribe seems to have been confused by the enteuxis in col. I as well (cf. appendix).

III. Io. The end of the line seems smudged, in a similar way to line 7 and I I of col. I. But here the addition is necessary to have a meaningful text, so it is difficult to interpret this as an erased mistake. It is possible, however, that the scribe wished to erase $i w p_{3}$ $w \underline{d} 3 m d n b$ nty $(r-) \underline{h} p_{3} y=w$ (?) $m k m k$ entirely, but forgot the first words of the sentence.

The original petition is not cited in its entirety here (cf. appendix), so this phrase must somehow refer to the complete version in the original memorandum..$^{56}$ The use of $w \underline{d} 3$ in this context is problematic, however. Quack has translated it as 'the rest', but in this case the word should have been feminine, $t 3 w \underline{d} 3(. t) .{ }^{57}$ In another article, Quack has made the connection between this group and the word for 'total sum', previously read r3, but 'total sum' does not seem to make much sense in this context. ${ }^{8}$ Unfortunately we have no good alternative for Quack's translation to offer.

III. I3. The initial $i w=f h b$ is an impersonal construction, like $i w=f s \underline{h}$ in line $\mathbf{r} 6$ and $n t y$ sh in line 18.

III. I4. $w n m d i w-i w=s ' h h_{3}=n(r) s h t=w$ at first sight looks like a positive statement. As it seems to be a literal quote of the subscription by Noumenios in col. II, line I6-I 7 (cf. appendix), the sentence must probably be a question without interrogative particle.

III. I 5. Starting from $t w=y$ vague traces of previous words can be seen, running further on the next line, where traces of $y$ and perhaps $i w$ can be discerned. Once more, the scribe seems to have corrected himself.

A strange vertical line can be observed just to the left of what looks like the $h$ of the word $h p . w$. Inspection of the original papyrus confirms that this is no shadow, but an actual line. The reading $h p . w$ fits the contents perfectly though and if the vertical stroke

\footnotetext{
54 Quack, in Jördens and Quack (eds), Ägypten zwischen innerem Zwist und äußerem Druck, 272.

55 w3h in Depauw, The Demotic Letter, 356; Quack, 'Das Diktum des Tutu', 272.

$5^{6} \quad$ For the writing of $w \underline{d} 3$, cf. supra note 46 . For the translation of $w \underline{d} 3$ as 'the rest', see: Hoffmann and Quack, in Dodson et al. (eds), A Good Scribe, I4I.

57 Quack, in Jördens and Quack (eds), Ägypten zwischen innerem Zwist und äußerem Druck, 272.

${ }_{5} 8$ Quack, in Vleeming (ed.), Aspects of Demotic Orthography, Io9-I I.
} 
would be taken into account, the first sign would be unintelligible. Probably some ink was sucked into the gap by capillary action.

III. I6. The scribe must have accidentally started the line with a word ending on $-y$, but corrected himself. There are also traces of another earlier writing that was replaced by $h p$. This erased word looks like the abbreviated form of '.wy, probably used at the end of line $\mathrm{I} 7$ as well. Probably Totoes intended to write $p_{3}$ ipt $m h-8 p 3$ '.wy wrr ('the eighth table (?), the prison'), but realised that this might be unclear for non-specialists. Therefore he erased '.wy and added (n) Kmy nty $i w=w \underline{d} d n=f n p 3$ '.wy (n) wrr: 'the eighth table (?) of the law of Egypt which is called prison"'.

The translation of $p 3$ ipt $m h-8 p 3 h p(n)$ Kmy as 'the eighth table of the law of Egypt' is very problematic. ${ }^{59}$ Previously, Nims has suggested to read 'the eighth scroll container of the law of Egypt', but that reading does not really convince either. ${ }^{60}$ We have followed the translation by Quack as we cannot suggest a better alternative. ${ }^{6 \mathrm{r}}$

III.I7. Quack has argued that 'wy n wrr should not be viewed as a prison here, but as 'Vorbehalt', i.e. 'caveat', 'reservation'. ${ }^{62}$ This translation would fit the context of this specific legal dispute much better. However, we do not know of other examples in which '. wy is used to construct an abstractum. Moreover, P. Berlin 23757 Ro shows that this ipt of the law of Egypt did not exclusively concern matters of caveats, since the law cited from it there deals with the punishment for people blaspheming against sacred animals. ${ }^{6}$ Perhaps the first paragraph of this section dealt with prisons and this became a nickname for the entire section, as suggested also by the use of $n t y i w=w d d$ $n=f$. Or, if '. wy can indeed be used to construct an abstractum, the beginning of this section might have dealt with caveats and lent this name to the entire section. We have retained the translation 'prison' here, already used by Lippert. ${ }^{64}$

The reading of the signs after $\underline{d} b_{3}$, partly lost in the $2 \mathrm{~mm}$ lacuna, is uncertain. Just like in line $\mathbf{5}$ a vertical line appears in the lost $\mathrm{I} \mathrm{mm}$ stroke. In this case it is unclear whether it should be read or not. It seems best to read an abbreviated form of $\underline{d} b_{3}$ .wy, like Lippert and Quack have done before. ${ }^{65}$ The same writing for '.wy seems to have been erased in line $\mathrm{r} 6$ and also appears in col. VI of the Vo, in lines I 7 and $\mathrm{I} 8$. Depauw's reading $\underline{d} b_{3}=w$, taking in account the vertical stroke, does not accommodate for the signs after the lacuna, and if one looks at the continuation of the sentence on the next line, one would expect some sort of property after $\underline{d} b_{3} .{ }^{66}$

III. I 8. Depauw's interpretation of $b_{3} k$ as 'document' perhaps fits the following $n t y s \underline{h}$ better, ${ }^{67}$ but it is hard to see why the exception would not be named expressis verbis. We

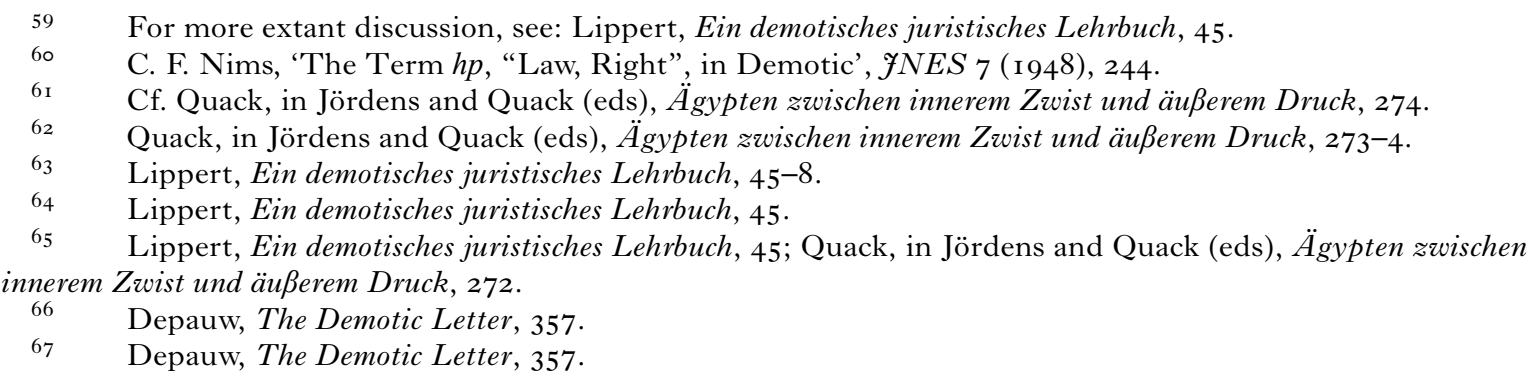


therefore follow Quack's translation as 'slave', standing for '(the case of a) slave', which is described elsewhere. We also follow Depauw's reading $m h t$ further in this line. ${ }^{68}$

III. I 9. Lippert has rightly noted that the beginning of the line reads $b w .{ }^{69}$ If one looks closely, one can see that the scribe wrote $r g$ directly after bw first, forgetting $i r=w$. He corrected himself, but while erasing the first $r g$, he accidentally rubbed out part of $b w$ as well.

\section{Interpretation}

Different interpretations of these texts have been offered. The first editor, Thompson, argued that the priests of Syene had undertaken legal action against Hetia and Wergi(r)a, who had made a claim to a part of their vineyard. Socrates ordered to deposit the title-deeds during litigation and Noumenios granted their official registration, after the priests had won their case. Now the priests petitioned for a return of their documents and further requested to hold back the wines of the current year until the government decided what was to be done with them. ${ }^{\circ}$ In Van 't Dack's view the priests wanted to collect evidence to bring their dispute with Hetia and Wergi(r)a before the king; furthermore they asked to hold back the wines of the current year, because they were needed for offerings in favour of the royal family. ${ }^{71}$ Locher offers a similar, but even more simplified interpretation: the priest's right to exploit their vineyard was disputed by Hetia and Wergi(r)a; to win their case, the priests had to collect evidence, so they asked Noumenios to give them their title-deeds. ${ }^{72}$

The story becomes more complex in the edition of Quack. He argues that the priests had in fact sold their vineyard, probably to Hetia and Wergi(r)a themselves, but the official ratification of the documents, started by Sokrates and continued by Noumenios, failed to arrive due to unforeseen problems. Possibly the procedure was more complex than in other cases because the sale concerned property from which royal offerings were brought. This situation was problematic for the priests: Hetia and Wergi(r)a already laid claim to the produce of the vineyard, while officially they did not yet possess the ownership and the priests were probably still subject to taxation. Consequently, they asked to protect the wines of the current year from Hetia and Wergi(r)a. This request was not approved by Totoes: according to Egyptian law, the actual property-owner retains the right of use of the property, until a binding judgement concerning it is registered. ${ }^{73}$

Several problems, however, arise from this interpretation. The priests' deposition of the sale's documents with the strategos shows clearly that they themselves were the buyers or owners, and not Hetia and Wergi(r)a. This acquisition of property might

68 Depauw, The Demotic Letter, 357; followed in Quack, in Jördens and Quack (eds), Ägypten zwischen innerem Zwist und äußerem Druck; contra Lippert, Ein demotisches juristisches Lehrbuch, 45 and Thompson, A Family Archive, 52.

69 Lippert, Ein demotisches juristisches Lehrbuch, 45; followed in Quack, in Jördens and Quack (eds), Ägypten zwischen innerem Zwist und äußerem Druck, 274; contra Depauw, The Demotic Letter, 357 and Thompson, A Family Archive, 52.

70 Thompson, A Family Archive, 49.

$7^{1} \quad$ Van't Dack, Ptolemaica selecta, 3 I 6.

72 Locher, Topographie und Geschichte, 89.

73 Quack, in Jördens and Quack (eds), Ägypten zwischen innerem Zwist und äußerem Druck, 274-5. 
have taken place many years before the priests' dispute with Hetia and Wergira. At a certain moment, however, Hetia and Wergi(r)a must have taken possession of part of the vineyard, presumably justified by some other documents or an inheritance claim. It is unnecessary to assume that there were problems in the ratification of the sales documents, as Quack interprets the text on the basis of the expression $g y(n) \underline{d} r^{\text {' }}-m d$ (cf. commentary I. I9-20). The priests contested this claim and wrote an enteuxis, possibly submitted directly to the king, and multiple memoranda to the strategos concerning the case (referred to in col. I, lines I I-I3; col. III, line 8). ${ }^{74}$ These petitions must have initiated legal proceedings, in the context of which the priests deposited their sales documents and other official correspondence with the strategos. The precise nature of the involvement of Sokrates, the former strategos of the districts in the surroundings of Syene, in these events is unclear. Was he responsible for the case before it was transferred to Noumenios? Or had Noumenios delegated the case to Sokrates in the first place, after he had received petitions from the priests? In any case, these first legal proceedings must have proved unsatisfactory. Perhaps Sokrates had died or had been transferred before being able to give a judgement. Alternatively, the first procedure may have gone principally in the favour of Hetia and Wergi(r)a.

The priests did not relax their efforts and in Mesore of year I I (August-September I $70 \mathrm{BC}$ ) they wrote a new memorandum to Noumenios, referred to at the very beginning of col. I (line 4; cited in col. III, line 5). In this petition they requested to return the documentation they had previously deposited with the strategos, in order to bring their case (for a second time?) before the king. Later in the same month they presented the memorandum of col. I-II, pointing to their previous petitions, repeating their request for the return of their documents and asking for a temporary provision to block the sale of the wines from the disputed property. By now, the priests seem to have lost their patience: Noumenios is warned to protect their interests; if not he risks divine retribution (col. I, line 22-col. II, line 2).

Noumenios hoped to gain Totoes' legal advice on the matter of blocking (sht) the wine sale: 'Is there something that impedes us from blocking them?' (col. II, line I6-I 7). The legal procedure of sht is also known from other sources of Egyptian law. ${ }^{75}$ Unfortunately, there is no law text about the sht of sales of produce from contested properties, but the procedure in P. Mattha VII.I8-VIII.4 does offer an interesting parallel. If a certain individual wanted to build a house on a piece of land and someone else contested the ownership of that individual to the land in question, the latter could put a stop $(s h t)$ to the construction works until the case was judged. If the builder did not interrupt his work, he risked a severe beating. If it turned out, however, that the land did rightfully belong to the person who wanted to build a house, that person could get

\footnotetext{
$74 \quad$ Normally, enteuxeis were submitted to and processed by the strategos (or the chrematistai) in replacement of the king, see: J. Hengstl, 'Petita in Petitionen gräko-ägyptischer Papyri', in G. Thür and J. VélissaropoulosKarakostas (eds), Symposion I995: Vorträge zur griechischen und hellenistischen Rechtsgeschichte (Cologne, I 997), 27I; Wolff, Das Fustizwesen, 9, I7. But in this case the priests state that the king gave the enteuxis to Noumenios. If this expression is to be taken literally, this might be one of the rare witnesses of the submission of petitions to the king himself. However, it might equally be a reflection of the ideological concept of the king as supreme judge, distributing royal justice through the practice of enteuxeis.

75 Cf. E. Seidl, 'Das private Verbot eines Baues nach dem Rechtsbuch von Hermopolis', in H. J. Thissen and K. T. Zauzich (eds), Grammata Demotika: Festschrift für Erich Lüddeckens zum I5. Funi I983 (Würzburg, I 984), I 89-92.
} 
reimbursed for any financial losses the interruption had caused. Presumably, a similar law existed for cases like the one Totoes was confronted with: if the ownership rights of a certain party (i.c. Hetia and Wergi(r)a) were contested, another party could put a stop to the sale of the produce from the disputed property. If it turned out, however, that the property in question did rightfully belong to the people who wanted to sell its produce, they could be reimbursed for any loss deriving from the sht procedure.

Strangely enough, the law that Totoes quotes, does not really help to elucidate Noumenios' question: 'if a trial is taking place about a house or other things except for a slave, which is written in the sixth law, the one who is holding it, it is not seized from his hand until the judgement is written down' (col. III, line I 7-I 9: in-n3.w wpy.t

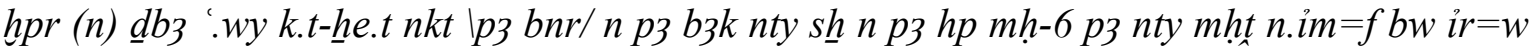
$\left.r g=f n-\underline{d} r . t=f \breve{s}^{\prime} . t w=w \underline{d} r^{\prime} t_{3} w p y\right)$. The verb mht ('to seize', 'to take in possession' or in the qualitative 'to have in possession') expresses factual possession, typically without full or uncontested property rights. ${ }^{76}$ During litigation, this factual possession is protected; dispossession $(\mathrm{rg}$ ) can only take place when the judgement concerning the disputed property has been written down. In this specific case, 'the one who is holding it' refers to Hetia and Wergi(r)a: their ownership is contested, but they cannot be dispossessed before the proceedings have ended. Still, what about the possibility of blocking (sht) the wine sales, without dispossessing $(r g)$ Hetia and Wergi(r)a already? Totoes fails to formulate an adequate answer on this point. How can this be explained? Did Totoes expect the strategos to know about the basic possibility of sht, only deeming it necessary to warn him to keep in mind the distinction between blocking the produce of the property and dispossessing Hetia and Wergi(r)a altogether? Perhaps he did not care to write down his entire answer in this draft (cf. below) and handed over a more elaborate version to Noumenios? Or perhaps Totoes was simply not the authority the strategos expected him to be, although this option seems unlikely, considering Totoes' position as scribe of the laokritai court in Ptolemais.

The administrative context of these texts has hitherto largely been ignored. The $m k m k$ is the Egyptian counterpart of the Greek vंró $\mu \nu \eta \mu \alpha$ (memorandum), the standard petitioning form in the Ptolemaic period. ${ }^{77}$ The original petition to Noumenios must have been written in Greek. It is unlikely that an official in his elevated position would have received Egyptian petitions. Moreover, typical formulae of Greek memoranda appear in the text (cf. col. II, lines 6-8, I3-I4). ${ }^{78}$ If these were Egyptian translations designed by Egyptian scribes that had become part of Egyptian discourse, they would

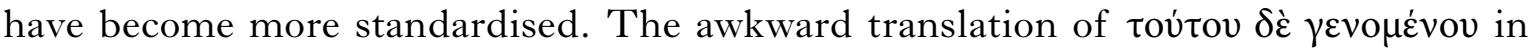
col. II, lines I3-I4 confirms that this had not become a set formula. Typical Egyptian constructions in the text (e.g. $b n-i w=n r h t m$ in col. I, lines 20-2 I) can originate from the translator(s). Egyptian topoi (especially the reference to Isis in col. I, line 24-col. II, line 2) do not need to contradict an original Greek version either. During the Ptolemaic period, the Egyptian clergy became increasingly hellenised; many priests were active in the Greek bureaucracy and spoke the Greek language. ${ }^{79}$ Therefore the priests of Syene were probably perfectly able to draft a Greek petition themselves, including Egyptian topoi.

76 Cf. P. Mattha 2, I 7; P. Mattha 8, 30.

77 Cf. G. Baetens, 'Demotic Petitioning', $\mathscr{7} \mathcal{F P}$ (forthcoming).

78 Cf. A. di Bitonto, 'Le petizioni ai funzionari nel period tolemaico', Aegyptus 48 (г968), 53-107. 
Noumenios read this Greek petition and added a subscription (col. II, lines I $5^{-1} 7$ ), still in the same month, referring the case to the Egyptian legal expert Totoes. This subscription was no doubt written in Greek, and it seems to have been rather polite, using a phrase which was rendered in Demotic by an optative. A second subscription (col. II, line I 8-20) is written one day later and follows underneath the first, in a noticeably less polite tone. ${ }^{8 \circ}$ Its presence is at first sight puzzling. Van 't Dack suggests this second subscription was added by the priest mentioned in col. III, lines 4, I3-I4, whom we have identified as the 'prophet of the northern gate' (cf. $p 3$ hm-ntr (n) r 3 mht above). He may have functioned as an intermediary between Noumenios and Totoes. ${ }^{8}$ This explanation seems plausible: Noumenios addressed the prophet, who served as intermediary, in a respectful way in the first, Greek subscription. The prophet, on the other hand, did not resort to formalities when he delegated the case through a second subscription to Totoes, although the latter seems to have been of some importance himself. The second subscription is very similar to another Egyptian subscription in a Greek petition. There the addressee of the petition, the royal scribe Horos, delegated

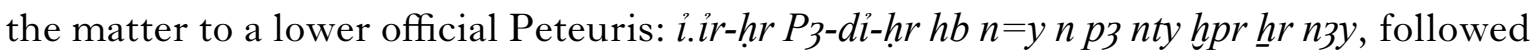
by the date. ${ }^{82}$

After these interventions, the petition thus probably consisted of the Greek main text as written by the priests in what in all likelihood was their second language, with a Greek subscription by the native speaker Noumenios, and a second, Demotic subscription by an almost equally important but unfortunately anonymous Egyptian prophet. This bilingual document was sent to the Egyptian legal expert, Totoes. Since the latter may have commanded Greek insufficiently, or perhaps rather because the laokritai administration wanted a copy of everything in their own indigenous language, the Greek parts of the petition were then translated. This resulted in a new, exclusively Demotic copy, translated by someone in the office of Noumenios, the anonymous prophet, or perhaps even Totoes himself. In any case, still in Mesore of year i I this Totoes wrote an answer to Noumenios' question: the text of col. III. We cannot know for sure if his advice, written in Egyptian, was translated into Greek before it reached the office of Noumenios (or that of the anonymous prophet).

The petition in col. I-II cannot be a draft, because we are certain that it was submitted, as illustrated by the subscriptions. Moreover the format with two narrow columns imitates that of the original, which was no doubt written on front and back of a narrow strip of papyrus, as customary for petitions and letters. The advice of

79 Cf. G. Gorre, Les relations du clergé égyptien et des lagides d'après des sources privées (Studia Hellenistica 45; Leuven, 2009), 557-603; H. Heinen, 'Ein griechischer Funktionär des Ptolemäerstaates als Priester ägyptischer Kulte', in B. Funck (ed.), Hellenismus: Beiträge zur Erforschung von Akkulturation und politischer Ordnung in den Staaten des hellenistischen Zeitalters (Tübingen, 1996), 339-53; W. Huß, Der makedonische König und die ägyptischen Priester: Studien zur Geschichte des ptolemaiischen Ägypten (Historia Einzelschrifte 85; Stuttgart, I 994), 72-90; A. B. Lloyd, 'The Egyptian Elite in the Early Ptolemaic Period: Some Hieroglyphic Evidence', in D. Ogden (ed.), The Hellenistic World: New Perspectives (London, 2002), I I 7-36; S. Pfeiffer, Das Dekret von Kanopos (238 v. Chr.): Kommentar und historische Auswertung eines dreisprachigen Synodaldekretes der ägyptischen Priester zu Ehren Ptolemaios’ III und seiner Familie (AfP Beihefte I8; Munich, 2004), 298-9.

8o Quack does not discuss the subscription in detail. He starts a new paragraph in his translation at the end of line $\mathrm{i} 8: h b n=n$. It is very implausible-judging from the contents as well as the position of this expression-that this would be the beginning of a subscription. In the present circumstances, however, it must remain uncertain whether the text is actually interpreted in this way.

8I Van't Dack, Ptolemaica selecta, 3 I 7.

$82 \quad$ P. Mich. Inv. 6956. 
Totoes in col. III, however, looks like a draft: several passages (cf. line 3, I5-I6) of the text have been rewritten and these corrections do not appear in the citation of the petition to Noumenios, but only in the parts that Totoes wrote himself. Therefore the text has to be a preliminary draft, perhaps intended to be copied in Greek afterwards. It is striking though that sections parallel with the petition to Noumenios often show variations (e.g. sht in col. III, line I 2 instead of the mistake shny.w in col. II, line ro) that are less easily explained if the text was a draft on the basis of col. I-II. Totoes may have noticed his mistakes when working on the draft in col. III or may have had the original translation of the petition at hand.

This brings us to the last problem, that of how to explain the presence of these documents in the Siut archive, on the verso of the trial report from the laokritai court in Siut. Except for col. III containing the advice of Totoes, and possibly col. IV, all documents on P. BM I059I seem to be copies of official documents, not drafts. ${ }^{8}$ On top of that, except for the three texts concerning the priests of Syene discussed here, all texts from the archive concern the inheritance dispute between Cratianch and Tefhape. The petition to Noumenios and advice of Totoes originate from the same period as their proceedings ${ }^{84}$ but this in itself does not warrant their presence amongst the other copies directly relevant for the legal proceedings. One possibility for the inclusion is that the case of the priests of Syene was relevant for the lawsuit, since righteous ownership of real property was also the object of dispute between Cratianch and Tefhape. But there are also many differences between both cases and one wonders why the texts would have been copied in their entirety if only the legal advice of Totoes was tangentially relevant. The fact that col. III appears to be a draft makes this hypothesis altogether untenable.

The Siut archive seems to have belonged to Tefhape. ${ }^{85}$ But the verso of P. BM г 059 I poses many questions. To the left of the advice of Totoes, four more columns are written on the verso:

- col. IV: a copy of a judicial order concerning the dispute between Cratianch and Tefhape;

83 Thompson cautiously identifies col. IV of the verso of P. BM I059I as a draft, because 'it is so imperfect and confused in places that it is not acceptable as the copy of an official decree': Thompson, A Family Archive, 53. Recently, however, Criscuolo has argued that copies in official archives of local authorities can be very sloppy; often copies seem to be mistaken for drafts: L. Criscuolo, 'Copie, malacopie, copie d'ufficio e il problema della titolarità di un archivio nell' Egitto tolemaico', in M. Faraguna (ed.), Archives and Archival Documents in Ancient Societies. Trieste 30 September-I October 201 I (Legal Documents in Ancient Societies 4; Trieste, 2013), 245-58.

${ }_{4} \quad$ Thompson, A Family Archive, x-xi.

$8_{5}$ The main document, P. BM r 059I, must have been kept by Tefhape, as he was the winning party and this document supported his claim to the property in question. P. BM I०575 is the deed of cession of Petetymis to Tefhape of I 8 I BC, signed by his half-brother. P. BM I0589 concerns private property of the mother of Tefhape. P. BM 10592, I0593 and 10594 are documents regarding the inheritance and marriage of the sister of Tefhape. P. BM 10595, I0596 and 10597 are two farming leases and a receipt from the period between the proceedings of I 73 $\mathrm{BC}$ and of $\mathrm{I} 70 \mathrm{BC}$, in which Totoes and Tefhape managed their lands together. P. BM I0598, I0599 and I0600 are petitions written by Tefhape. P. BM г 598 . P. BM го6о I is a receipt given by Totoes to Tefhape. Its date is lost, but it probably belongs to the period in which Totoes and Tefhape were joint owners as well. For P. BM ro598 and P. BM Iо6ог, see: Shore and Smith, $\mathscr{F E A ~ 4 5 , ~ 5 2 - 6 0 ; ~ f o r ~ t h e ~ o t h e r ~ t e x t s , ~ s e e ~ T h o m p s o n , ~ A ~ F a m i l y ~ A r c h i v e . ~}$ Manning suggests that the Siut archive might be a (partial) archive of a court or advocate from Ptolemais, but this would not accomodate for the presence in the archive of the documents concerning the inheritance and marriage of Tefhape's sister and the private property of his mother: Manning, in Baker, Jursa, and Täuber (eds), Administration, Law and Administrative Law. Moreover, it seems too much of a coincidence that all preserved documents from such an archive would be related to Tefhape and his family. Therefore Thompson seems to have been right in calling this group of texts a family archive from Siut: Thompson, A Family Archive, i. 
- col. V-VII: a copy of an apportionment deed made to the husband of Cratianch, submitted to court by Cratianch.

All documents on the verso seem to be written in one hand, distinct from the hand of the recto. ${ }^{86}$ If col. III is a draft by Totoes himself, this scribe, who worked for the laokritai court in Ptolemais (cf. col. III, line $\mathrm{I}-2$ ), must have copied all other texts on the verso as well. From col. IV of the verso it appears that Cratianch aimed to obtain a new ruling at Ptolemais after she had lost the proceedings at Siut. During this trial, Totoes may have written down the documents on the verso before returning the papyrus to Tefhape. More research, however, on the enigmatic fourth column of the verso is necessary and might further clarify this fascinating ensemble of texts.

\section{Appendix: comparison between citations in col. I-II and col. III}

\begin{tabular}{|c|c|}
\hline Col. I-II & Col. III \\
\hline$t w=n n=k w^{`} m k m k$ & $t w=n n=k w^{\prime} m k m k$ \\
\hline$i w=n i r-w 3 h r n 3 y=n$ md.w & - \\
\hline$i w=n t b h \underline{h} n-i m=s r d y n=n n_{3} s \underline{h} . w$ & $i w=n t b h n-i m=s r d y n=n n_{3} s \underline{h} . w$ \\
\hline |sh knnb.t| & - \\
\hline$r . h 3^{`}=n$ i. ir $r-h r=k$ & $r . h 3^{`}=n$ i.i $i r-h r=k$ \\
\hline$[[r-\underline{h} \ldots]]$ & - \\
\hline 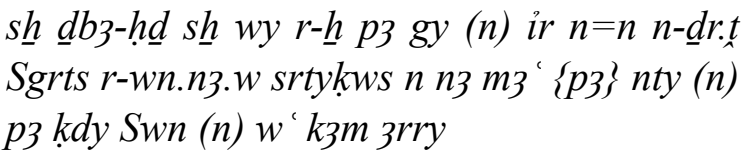 & 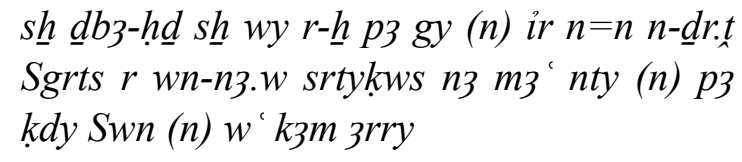 \\
\hline irm t3 $[[\check{s} . t]]($ (?) $3 n t k s$ & lirm 3ntk [s] \\
\hline$r$-tw Pr-' 3 c.w.s. in $=w n=k$ & - \\
\hline irm nз mkmk.w r-tw $=n n=k$ & irm nз mkmk.w r.in $=n$ i.ir $-h r r=k$ \\
\hline irm n3 hnn.w r-in $=n r-\underline{h} n$ i.ir $r-h r=k$ & - \\
\hline$h p r=f i w=n(r) i n=w m-b 3 h P r-3$ c.w.s. & $h p r=f i w=n(r) \underline{t} 3 y$ i.ir $h r \operatorname{Pr}-{ }^{\prime} 3$ ‘w.s./ \\
\hline $\begin{array}{l}m t w=f(r) h p r \text { t3 } n t y i w=f h n=s i w=w(r) i r \\
r-\underline{h} . t=s\end{array}$ & - \\
\hline 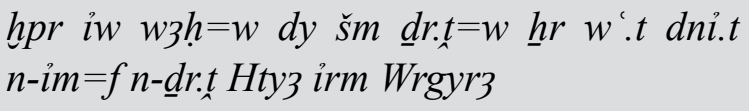 & $\begin{array}{l}i w \quad w 3 h=w d y \quad \check{s} m=w \quad \underline{d} r . t=w \quad h r \quad w ' t \text { dni.t } \\
n . i m=f n-\underline{d} r . t \text { Htyz irm Wrgy3 }\end{array}$ \\
\hline / & $i w p_{3}$ wd 3 md nb m3 'n pз mkmk \\
\hline
\end{tabular}

Table continues overleaf

86 Most obvious in this respect is the different writing for the name Totoes (Twt), with the two last signs always in ligature on the verso. Another distinctive feature of the hand of the verso are the dots that appear regularly before $p_{3}$ (cf. supra, note concerning col. III, line 4). 


\begin{tabular}{|c|c|}
\hline Col. I-II & Col. III \\
\hline$(\ldots)$ & - \\
\hline$t w=n t b h n . i m=s$ & $i w=w$ tbh $n \cdot i m=s$ \\
\hline$m t w=k i w-\imath w=s h s$ & - \\
\hline 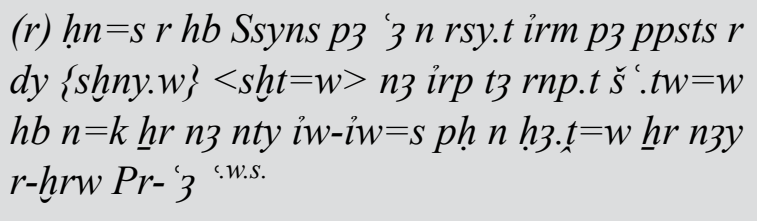 & 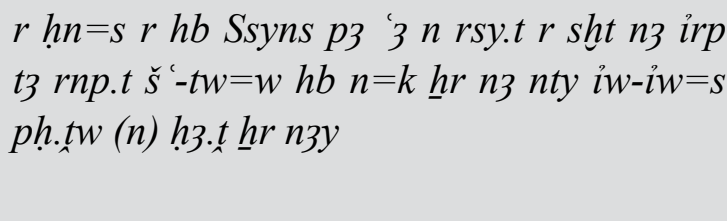 \\
\hline$(\ldots)$ & - \\
\hline$m y$ in $=w$ s i.ir $-h r$ r Twt $m t w=w \check{s} n . t=f \underline{d} d d$ & $i w=f h b$ i.ir-hr pз $h m-n \underline{t} r$ (n) rз mht (?) \\
\hline$\{i w\}$ wn $m d i w-i w=s ' h{ }^{\prime} h{ }^{\prime}=n r s h t=w$ & wn $m d i w-i w=s ' h^{\prime} h h_{3}=n(r) s h t=w$ \\
\hline
\end{tabular}

